\title{
PENGARUH PERILAKU KEPEMIMPINAN KEPALA SEKOLAH DAN BUDAYA ORGANISASI TERHADAP KINERJA GURU PENDIDIKAN AGAMA ISLAM DI SD, SMP, SMA DAN SMK SE KABUPATEN FAKFAK
}

\author{
Oleh \\ Zainuddin \\ Pascasarjana Universitas Islam Negeri Maulana Malik Ibrahim Malang \\ zaenuddinbustany@gmail.com
}

\begin{abstract}
:
Leadership behavior is individual behavior a leader (Principal) which directs group activities to achieve common goals. Organization culture refers to a system of all meaning shared by members that is distinguishes from other organizations, this system of all meaning, when observe is a set of key characteristics appreciated by the organization. The Islamic Education Teachers Performance is achievements that achieved by a teacher of Islamic Education in carrying out duties for a certain period According to competency standards and predefined criteria. The Influence of Leadership Behavior Principal and Organization Behavior can have an effect on Islamic education teacher performance. The purpose of studies are (1) Explain the level of leadership behavior, organizational culture, and Islamic education teacher performance, (2) Explain the influence of leadership behavior on Islamic Education teacher performance, (3) Explain the influence of organizational culture on teacher performance and (4) Explain the influence of leadership behavior, organization culture on Islamic education teacher performance at Fakfak.

The results of data processing known that are (1) from 45 respondent more than $80 \%$ has agreement about the important of leadership behavior principle, organization culture and increasing teacher's performance. (2) There are a positive and significant influence on leadership behavior, and organizing culture on the Islamic religious education teachers performance, explain data value is Fcount $(82,142)$ $>$ Ftable 3,219 significance $0.000<0,005$, (3) There are positive influence and significance leadership behavior on Islamic religious education teachers performance, its show on value of counted $(7,460)>t$-table 2,018 and significance t-test $0.000<0,005$, (4) there are positive influence and significance organization culture on Islamic education teacher performance, its explain with data value t-count $(3,451)>t$ table2,018 and significance t-test $0.001<0,005$, (5) There are positive influence and significance simultaneously leadership behavior, organization culture on Islamic education teacher in elementary school, junior high school and senior high school at Fakfak. The result of
\end{abstract}


analysis test $\mathrm{F}$ with significance value $0.000<0,005$. High $\mathrm{R}$ square is 0,787 , its mean $78,7 \%$ and balance $21,3 \%$ effected by other variable in addition to two variables like leadership behavior and Organization behavior.

Key Words: Leadership Behavior, Organizational Culture, and Teacher's Performance

\section{A. Pendahuluan}

Manusia membutuhkan pendidikan dalam kehidupannya. Pendidikan merupakan usaha sadar agar manusia dapat mengembangkan potensi dirinya melalui proses pembelajaran dan atau cara lain yang dikenal dan diakui oleh masyarakat. Pendidikan nasional bertujuan untuk berkembangnya potensi peserta didik agar menjadi manusia yang beriman dan bertakwa kepada Tuhan Yang Maha Esa, berakhlak mulia, sehat, berilmu, cakap, kreatif, mandiri, dan menjadi warga negara yang demokratis serta bertanggung jawab. ${ }^{1}$

Banyak faktor yang menentukan/mempengaruhi tercapainya tujuan pendidikan. Diantaranya kurikulum, sarana prasarana, kualitas proses pembelajaran, manajemen pembiayaan, manajemen sumber daya manusia (SDM) dan lain-lain. Diantara beberapa faktor tersebut, pendidik/guru merupakan faktor dominan dalam menentukan tercapainya tujuan pendidikan. Pendidik adalah tenaga kependidikan yang berkualifikasi sebagai guru, dosen, konselor, pamong belajar, widyaiswara, tutor, instruktur, fasilitator, dan sebutan lain yang sesuai dengan kekhususannya, serta berpartisipasi dalam menyelenggarakan pendidikan. $^{2}$

Tercapainya tujuan pendidikan diawali dari keberhasilan proses pembelajaran. Dalam proses pembelajaran, seorang guru termasuk di dalamnya guru pendidikan Agama Islam, memegang peranan penting karena gurulah yang secara langsung berinteraksi dengan peserta didik. Oleh karena itu, keberadaan guru yang profesional dan berkinerja baik merupakan syarat mutlak terciptanya sistem dan praktek pendidikan yang berkualitas. Guru bukan hanya sekedar mengajar, lebih dari itu guru merupakan pendidik profesional yang harus melaksanakan tugasnya dengan baik dan bermutu. Keberhasilan pendidikan dalam proses

1Undang-Undang RI Nomor 20 Tahun 2003 tentang Sistem pendidikan Nasional, (Yogyakarta: Pustaka Yustisia, 2011), hlm. 145,

2Peraturan Pemerintah RI No. 66 tahun 2010 tentang Pengelolaan dan Penyelenggaraan Pendidikan, (Yogyakarta: Pustaka Yustisia, 2011), hlm. 101.

256 JURNAL LISAN AL-HAL 
pembelajaran ditentukan oleh kinerja guru, termasuk guru Pendidikan Agama Islam.

Kinerja seorang guru diharapkan dapat berfungsi dan berperilaku sesuai dengan tugas yang telah dibebankan kepadanya. Tinggi rendahnya kinerja seorang guru dipengaruhi oleh banyak hal, diantaranya efektivitas dan efisiensi kerja, otoritas dan tanggung jawab, disiplin, dan inisiatif. ${ }^{3}$ Ahmad Susanto mengatakan bahwa kinerja seorang guru dipengaruhi oleh beberapa faktor, antara lain ciri seseorang, lingkungan luar, dan sikap terhadap profesi pegawai. ${ }^{4}$ Berdasarkan hal tersebut maka peningkatan terhadap kinerja guru harus dilaksanakan guna terciptanya tenaga pendidik yang profesional yang tidak hanya sekedar pengajar melainkan sekaligus sebagai pendidik. Peningkatan kualitas kinerja guru bisa dilakukan dengan kegiatan diklat/pelatihan, peningkatan disiplin diri, pengelolaan sarana dan prasarana yang baik, serta dukungan/motivasi dari kepala seolah sebagai pimpinan lembaga.

Pada dasarnya kualitas pendidikan di sebuah lembaga ditentukan oleh kualitas kinerja warga sekolahnya, utamanya adalah guru. Untuk itu pengembangan mutu guru dan penilaian kinerja guru merupakan hal penting untuk dilakukan. Penelitian Heyniman dan Loxley sebagaimana dikutip oleh Eko Putro Wijoyoko mengemukakan bahwa diantara berbagai masukan (input) yang menentukan kualitas pendidikan sepertiganya ditentukan oleh guru. ${ }^{5}$

Kinerja guru yang baik dan produktif akan berdampak positif terhadap motivasi belajar siswa, motivasi berprestasi siswa dan capaian maksimal di hasil akhir pendidikan, sebagaimana penelitian yang dilakukan oleh, Novi Biya ${ }^{6}$ dan Anita Rinwati. ${ }^{7}$

Terciptanya kinerja guru yang baik dan produktif dipengaruhi oleh banyak faktor. Salah satu faktor yang mempengaruhi kinerja guru yaitu perilaku kepemimpinan kepala sekolah. ${ }^{8}$ Perilaku kepemimpinan kepala sekolah sebagai pimpinan lembaga sekaligus pemangku kebijakan

${ }^{3}$ Edy Sutrisno, Budaya Organisasi, (Jakarta: Prenamedia Group, 2015), hlm. 176.

${ }^{4}$ Ahmad Susanto, Managemen peningkatan kinerja guru, (Prenamedia, kencana Jakarta 2016) hlm.74.

5Eko Putro Wijoyoko, Analisi Pengaruh Kinerja Guru terhadap Motivasi Belajar Siswa, Jurnal Pendidikan 2015.

${ }^{6}$ Novi Biya, Pengaruh Kinerja Guru terhadap Hasil Belajar Siswa Mata Pejaran Ekonomi, Jurnal Muhammadiyah Gorontalo, 2012.

${ }^{7}$ Anita Rinwati, Pengaruh Kinerja Guru terhadap Motivasi Belajar Siswa, Jurnal Universitas Muhammadiyah Purworejo (Vol. 2 Juni 2012).

'Wahjosumidjo, Kepemimpinan Kepala Sekolah, Tinjauan Teoritik dan Permasalahannya Kepala Sekolah,(Jakarta: PT. Raja GrafindoPersada, 1999), hlm. 83. 
berimplikasi terhadap kinerja bawahannya (guru dan tenaga kependidikan). Kepala sekolah harus mampu memberikan solusi terhadap permasalahan yang mungkin timbul dalam lembaganya, utamanya permasalahan yang berkaitan dengan proses pembelajaran. Oleh karena itu kepala sekolah harus bisa menjadi contoh atau teladan bagi bawahannya, seorang pemimpin harus mampu memiliki perilaku kepemimpinan yang baik sebagaimana keteladanan yang dimiliki oleh Rasulullah.

Perilaku kepemimpinan yang diterapkan oleh kepala sekolah akan membantu guru agar mampu bekerja dengan baik dan optimal guna mewujudkan eksistensi dan keberhasilan sebuah lembaga. Keberhasilan suatu lembaga tergantung pada bagaimana pimpinan lembaga tersebut bersikap dan bertingkah laku. Dalam melaksanakan tugas, setiap pemimpin atau kepala sekolah erat kaitannya dengan kemampuan mempengaruhi bawahannya untuk mencapai tujuan yang ditetapkan.

Perilaku-perilaku pemimpin dalam proses memberikan pengaruh dapat menimbulkan pada perilaku bawahan. Perilaku yang dipersepsi positif oleh bawahan, secara otomatis akan menimbulkan sikap positif pula pada lembaga. Sebaliknya jika perilaku yang ditunjukkan dinilai negatif maka akan memunculkan sikap negatif pula dari para bawahannya. Munculnya sikap negatif akan berdampak pada penurunan kepuasan kerja dan penurunan kinerja, sebaliknya munculnya sikap positif akan berdampak pada peningkatan kinerja guru. ${ }^{9}$ Pendapat tersebut sesuai dengan penelitian yang telah dilakukan oleh Sri Rahayu dengan hasil penelitian bahwa kepemimpinan kepala sekolah berpengaruh positif dan signifikan terhadap kinerja guru. ${ }^{10}$ Dan beberapa peneliti lain, diantaranya Deriana Rekno Wulan, ${ }^{11}$ Atik Novitasari, Agus Wahyudi, Rediana setiyani, ${ }^{12}$ Roslen Septiana, Ngadiman, Elvia Ivada, ${ }^{13}$ Donal M.F. Tiogas, ${ }^{14}$ hlm. 5.

${ }^{9}$ Saiful Bahri, Optimalisasi Kinerja Kepala Sekolah, (Jakarta: Gibon Books, 2010),

10 Sri Rahayu Wahyuningsih, Tesis Pengaruh Kepemimpinan Kepala Sekolah Terhadap Kinerja Guru Sd Negeri Di Lingkungan Unit Pelaksana Teknis Pendidikan Kecamatan Sukagumiwang Kabupaten Indramayu, 2011 Jakarta.

${ }^{11}$ Deriana Rekno Wulan, Pengaruh Supervisi dan Kepemimpinan Kepala Sekolah terhadap Motivasi untuk Peningkatan Kinerja Guru, 2015.

${ }^{12}$ Atik Novitasari, Agus Wahyudin, Rediana Setiyani, Pengaruh Kepemimpinan Kepala Sekolah, Lingkungan Kerja Pendidikan, dan Pelatihan terhadap Kinerja,(Economic Education Analysis Journal, Vol. 1 No. 2), 2012.

${ }^{13}$ Roslen Septiana, Ngadiman, Elvia Ivada, Pengaruh Kepemimpinan Kepala Sekolah dan Motivasi Kerja terhadap Kinerja Guru PAI Wonosari, (Jurnal Pendidikan Ekonomi, Vol 2 No. 1), 2013.

258 JURNAL LISAN AL-HAL 
Yulia Noordianti, ${ }^{15}$ dan Sulistiani. ${ }^{16}$ Hasil penelitian mereka menyebutkan bahwa perilaku kepemimpinan kepala sekolah berpengaruh positif dan signifikan terhadap kinerja guru.

Faktor lain yang juga mempengaruhi kinerja guru adalah lingkungan dimana guru tersebut bekerja, termasuk di dalamnya adalah budaya organisasi yang terbentuk. ${ }^{17}$ Sebagai makhluk sosial, guru tidak terlepas dari berbagai nilai dan norma yang ada di lembaga sekolah. Budaya organisasi dapat mempengaruhi cara guru berperilaku, orientasinya terhadap tugas, cara bermitra dengan teman sejawat, dan cara memandang masa depan dengan wawasan yang ditentukan oleh norma, nilai dan kepercayaannya. Norma, nilai dan kepercayaan setiap individu pada suatu organisasi menjadi suatu budaya di organisasi tersebut.

Budaya organisasi yang kuat akan membantu lembaga pendidikan dalam memberikan kepastian kepada seluruh guru untuk berkembang bersama guna menciptakan kinerja yang baik dan berorientasi terhadap tercapainya keberhasilan pendidikan di sebuah lembaga. Hal ini sesuai dengan penelitian yang dilakukan oleh Ida Ayu Brahmasari dan Agus Suprayitno (2008), dengan hasil penelitian bahwa variabel budaya organisasi berpengaruh positif dan signifikan terhadap kinerja karyawan. ${ }^{18}$ Demikian pula Ester Manik dan Kamel Bustomi, ${ }^{19}$ I Nyoman Rauh, Dantes, Anggan, ${ }^{20}$ Yonatan Steve Kosasih, ${ }^{21}$ Rikha Handayani,

14 Donald M.F. Tiogas, Pengaruh Kepemimpinan Kepala Sekolah, Supervisi dan kepuasan Kerja Guru terhadap Kinerja Guru MIPA di Yayasan Pendidikan Advent Timika, (Jurnal lmu Pendidikan Indonesia, Vol. 2 No. 3), 2014.

${ }^{15}$ Yulia Noordianti, Pengaruh Perilaku Kepemimpinan, Kepala Sekolah, Iklim Kerja dan Motivasi Kerja terhadap Kinerja Guru, (Jurnal Manajemen, Surakarta), 2013.

${ }^{16}$ Sulistiani, Pengaruh Kepemimpinan Kepala Sekolah, Iklim Kerja, Kompetensi Profesional Guru terhadap Kinerja Guru di MTs Kepanjen, (Jurnal Riset Pendidikan Ekonomi, Vol. 1 No. 1), 2016.

${ }^{17}$ Firmanika Rozaki, Pengaruh Motivasi dan Budaya Organisasi terhadap Kinerja Guru SMK YPT 2 Purbalingga, (jurnal e Abstract Excellent Vol. 2 No. 2), 2016.

${ }^{18}$ Ida Ayu Brahmasari dan Agus Suprayitno, Jurnal Manajemen dan Kewirausahaan, VOL.10, NO. 2, September 2008: hlm. 124-135.

${ }^{19}$ Ester Manik dan Kamel Bustomi, Jurnal Ekonomi, Bisnis \&Entrepreneurship Vol. 5, No. 2, Oktober 2011, 97-107 ISSN 2443-0633.

${ }^{20}$ I Nyoman Rauh, Dantes, Anggan, Kontribusi Gaya Kepemimpinan, Supervisi Akademik Kepala Sekolah, dan Budaya Organisasi terhadap Kinerja Guru SD di Gugus III Kecamatan Sukasada, (e-jurnal Program Pasca Sarjana Universitas pendidikan Ganesha, Vol. 4), 2013.

21Yonatan, Pengaruh Budaya dan Komitmen Organisasional terhadap Kinerja 
Yusrawati, $^{22}$ Samsul Bahri, ${ }^{23}$ dan Firmanika Rozaki ${ }^{24}$ dengan hasil penelitian bahwa budaya organisasi berpengaruh positif dan signifikan terhadap kinerja guru.

Dalam hal ini maka budaya organisasi bukan sekedar berdampak pada kinerja, tetapi juga dapat mengakibatkan kepuasan kerja di kalangan guru. Dampak terhadap kinerja terjadi apabila budaya organisasi memberikan iklim yang kondusif bagi guru untuk melaksanakan tugas dengan baik. Sedangkan kepuasan kerja guru akan dicapai apabila nilainilai budaya organisasi sesuai dengan harapan keinginan dan kebutuhan guru dalam bekerja. ${ }^{25}$

Penelitian terkait perilaku kepemimpinan kepala sekolah, budaya organisasi dan kinerja guru selama ini memang sudah banyak dilakukan, namun peneliti perlu melakukan penelitian kembali terkait kinerja guru dengan alasan sebagai berikut: (1) selama ini penelitian terkait kinerja guru mayoritas dilakukan hanya di satu jenjang pendidikan, sedangkan penelitian yang dilakukan di seluruh jenjang pendidikan, baik di SD, SMP, maupun SMA/SMK masih jarang ditemukan; (2) penelitian yang fokus terhadap kinerja guru PAI khusunya di daerah Papua masih jarang ditemukan.

Berdasarkan hal tersebut di atas, maka peneliti tertarik untuk melakukan penelitian tentang "Pengaruh Perilaku Kepemimpinan Kepala Sekolah dan Budaya Organisasi terhadap Kinerja Guru Pendidikan Agama Islam di Kabupaten Fakfak". Maka yang menjadi fokus perhatian problem sebagai berikut: 1) Bagaimana tingkat perilaku kepemimpinan kepala Sekolah, budaya organisasi, dan kinerja Guru Pendidikan Agama Islam di Kabupaten Fakfak? 2) Adakah pengaruh perilaku kepemimpinan kepala Sekolah terhadap kinerja Guru Pendidikan Agama Islam di Kabupaten Fakfak? 3) Adakah pengaruh budaya organisasi terhadap kinerja Guru Pendidikan Agama Islam di Kabupaten Fakfak? 4) Adakah pengaruh perilaku kepemimpinan kepala sekolah dan budaya organisasi secara

Karyawan, (Jurnal Agora, Vol. 2 No. 1), 2014.

${ }^{22}$ Rikha Handayani, Yusrawati, Pengaruh Profesionalisme, Komitmen Organisasi dan Budaya Kerja terhadap Kinerja Internal, (Jurnal Manajemen Ekonomi, Vol. 21 No. 2), 2013.

${ }^{23}$ Samsul Bahri, Pengaruh Motivasi, Tindakan supervisi dan Budaya Organisasi terhadap Kinerja Auditor Junior), (Jurnal Fakultas Ekonomi dan Bisnis UIN Syarif Hidayatullah), 2012.

${ }^{24}$ Firmanika Rozaki, Pengaruh Motivasi dan Budaya Organisasi terhadap Kinerja Guru SMK YPT 2 Purbalingga, (jurnal e Abstract Excellent Vol. 2 No. 2), 2016. hlm. 4.

${ }^{25}$ Saiful Bahri, Optimalisasi Kinerja Kepala Sekolah, (Jakarta: Gibon Books, 2010),

$260 \mid$ JURNAL LISAN AL-HAL 
bersama-sama terhadap kinerja Guru Pendidikan Agama Islam di Kabupaten Fakfak?

\section{B. Metode Penelitian}

Penelitian ini mengkaji pengaruh Perilaku Kepemimpinan Kepala Sekolah dan Budaya Organisasi terhadap Kinerja Guru Pendidikan Agama Islam tingkat SD, SMP SMA dan SMK Se Kabupaten Fakfak Papua Barat. Adapun metode yang digunakan dalam penelitian ini adalah metode penelitian kuantitatif dengan jenis korelasional, yaitu penelitian yang berusaha menghubungkan dua variabel bebas dan satu variabel terikat berdasarkan fakta-fakta yang telah terjadi melalui pengumpulan data, pengolahan data, kemudian menganalisis dan terakhir menjelaskan.

Populasi yang digunakan dalam penelitian ini adalah seluruhguru PAI tingkat SD sebanyak 26 lembaga yang terdiri dari 27 orang, tingkat SMP sebanyak 9 lembaga yang terdiri dari 10 orang dan tingkat SMA/SMK sebanyak 7 lembaga yang terdiri dari 8 orang dengan jumlah guru PAI di seluruh Kabupaten Fakfak sebanyak 45 orang. Teknik pengumpulan data yang digunakan adalah teknik questionare dengan instrumen berupa angket. Untuk mengukur validitas instrumen peneliti menggunakan rumus product moment, sedangkan untuk mengukur tingkat reliabilitasnya peneliti menggunakan rumus alpha cronbach.

Dalam penelitian ini teknik analisis data yang digunakan ada tiga, yaitu: 1) analisis deskriptif; 2) uji persyaratan analisis; dan 3) pengujian hipotesis. Analisis deskriptif digunakan untuk menggambarkan tingkat persetujuan responden terhadap masing-masing variabel. Uji pra syarat analisi yang digunakan dalam penelitian ini terdiri dari uji normalitas dan uji linieritas. Uji hipotesis secara parsial digunakan untuk mengetahui pengaruh masing-masing variabel independent terhadap variabel dependet dengan cara membandingkan antara $t_{\text {hitung }}$ dengan $t_{\text {tabel }}$ Sedangkan untuk uji hipotesis simultan digunakan untuk mengetahui pengaruh secara simultan antara kedua variabel independent terhadap variabel dependent dengan cara membandingkan antara $F_{\text {hitung }}$ dengan $\mathrm{F}_{\text {tabel. }}$

\section{Kepemimpinan Kepala Sekolah}

Peran dari kepala sekolah sebagai pemimpin adalah menjadi kunci dari peningkatan atau perkembangan sekolah, sehubungan dengan hal tersebut Oteng Sutisna ${ }^{26}$ mengemukakan bahwa jika kita menerima

${ }^{26}$ Oteng Sutisna, Administrasi Pendidikan Dasar Teoritis untuk Praktik Profesional,

$$
\text { JURNAL LISAN AL-HAL } \mid 261
$$


asumsi bahwa maksud utama sekolah adalah tercapainya lingkungan yang kreatif dimana proses pembelajaran bisa dicapai dengan efektif maka kita harus menarik kesimpulan bahwa peranan pokok kepala sekolah terdapat dalam kesanggupan untuk memengaruhi lingkungan serupa itu melalui perilaku yang dinamis.

Kepala sekolah sebagai pemimpin berkewajiban untuk meningkatkan kinerja guru. Kepala sekolah juga memiliki tanggung jawab dalam penyelenggaraan pendidikan untuk mengembangkan sumber daya manusia di sekolah. Melalui perilaku kepemimpinan seorang kepala ekolah sebagai pemimpin akan sangat mempengaruhi kondisi kerja, dimana guru menerima suatu perilaku kepemimpinan yang ditampilkan senang atau tidak, suka atau tidak. Hal ini menyebabkan peningkatan kinerja, atau sebaliknya juga bisa menyebabkan penurunan kinerja guru yang nantinya akan berdampak pada kualitas lulusan. ${ }^{27} \mathrm{Hal}$ ini senada dengan penelitian yang dilakukan oleh Sri Rahayu Wahyuningsih dengan hasil penelitian bahwa kepemimpinan kepala sekolah berpengaruh positif dan signifikan terhadap kinerja guru. ${ }^{28}$

Pengaruh Budaya Organisasi terhadap Kinerja Guru Pendidikan Agama Islam.Budaya Organisasi yang diterapkan oleh suatu sekolah menuntut para anggota organisasi untuk menyesuaikan diri terhadap budaya organisasi yang merupakan ciri khas suatu lembaga. Setiap calon anggota yang akan masuk ke dalam organisasi diharuskan menyesuaikan diri dengan budaya yang ada di lembaga.

Budaya organisasi yang dianut oleh sekolah merupakan sarana untuk meningkatkan kinerja guru dan para pegawai lainnya. Meningkatnya kinerja guru merupaka hasil internalisasi guru terhadap nilai-nilai organisasi sekolah sehingga memunculkan loyalitas serta komitmen yang tinggi kepada sekolah yang pada akhirnya berdampak pada peningkatan kinerja guru. ${ }^{29}$

Kotter dan Heskett sebagaimana dikutip oleh Susanto mengemukakan bahwa nilai-nilai, norma-norma, dan asumsi-asumsi

(Bandung: Angkasa, 1993), hlm. 273.

${ }^{27}$ Ahmad Susanto, Managemen peningkatan kinerja guru, (Prenamedia, kencana Jakarta 2016) hlm. 98.

28 Sri Rahayu Wahyuningsih, Tesis Pengaruh Kepemimpinan Kepala Sekolah Terhadap Kinerja Guru Sd Negeri Di Lingkungan Uptd Pendidikan Kecamatan Sukagumiwang Kabupaten Indramayu, 2011 Jakarta.

${ }^{29}$ Ahmad Susanto, Managemen peningkatan kinerja guru, (Prenamedia, kencana Jakarta 2016) hlm. 202.

$262 \mid$ JURNAL LISAN AL-HAL 
yang diinternalisasi dan dipegang teguh oleh para anggota organisasi dapat melahirkan perasaan tenang, loyalitas, memacu kerja lebih keras, keseragaman sasaran, dan mengendalikan perilaku anggota organisasi serta produktivitas dan kinerja. ${ }^{30}$ Sehubungan dengan hal tersebu, maka budaya organisasi yang yang dianut dan diterapkan oleh suatu sekolah tertentu, akan mampu memengaruhi kinerja guru dan pegawai di sekolah yang bersangkutan. Hal ini sesuai dengan penelitian yang dilakukan oleh Ida Ayu Brahmasari dan Agus Suprayitno (2008), dengan hasil penelitian bahwa variabel budaya organisasi berpengaruh positif dan signifikan terhadap kinerja karyawan. ${ }^{31}$

Pengaruh Perilaku Kepemimpinan Kepala Sekolah dan Budaya Organisasi terhadap Kinerja Guru Pendidikan Agama Islam. Perilaku Kepemimpinan kepala sekolah adalah segala tindakan, reaksi, aktivitas tanggapan dari seorang pemimpin (kepala sekolah) dalam bertindak dan merespon lingkungan sekitarnya dalam rangka menjalankan kepemimpinannya sebagai pimpinan sekolah. Kepemimpinan kepala sekolah dipersepsi oleh guru sebagai perilaku yang berorientasi pada bawahan dalam hubungan pribadi maupun hubungan formal (kedinasan) pada lingkungan sekolah. ${ }^{32}$

Budaya Organisasi adalah suatu bentuk atau cara yang digunakan dalam pemecahan masalah organisasi, baik intern maupun ekstern yang mencakup: filosofi, ideologi, values, asumsi, keyakinan, harapan, sikap, dan norma-norma yang dirajut bersama oleh anggota organisasi dan digunakan dalam pembuatan keputusan dan pemecahan masalah. ${ }^{33}$

Dari hasil analisis yang diteliti diperoleh kesimpulan bahwa perilaku kepemimpinan kepala sekolah, budaya organisasi dan kinerja guru Pendidikan Agama Islam mempunyai suatu hubungan satu sama lain. Masing-masing variabel dependent berpengaruh signifikan terhadap variabel independent. Beberapa penelitian terkait perilaku kepemimpinan kepala sekolah, budaya organisasi dan kinerja telah dilakukan oleh beberapa peneliti diantaranya oleh Atik Novitasari, Agus Wahyudi, Rediana setiyani ${ }^{34}$ yang menyimpulkan bahwa perilaku kepemimpinan

\footnotetext{
${ }^{30}$ Ahmad Susanto, Managemen peningkatan kinerja guru, (Prenamedia, kencana Jakarta 2016) hlm. 203.

${ }^{31}$ Ida Ayu Brahmasari dan Agus Suprayitno, Jurnal Manajemen dan Kewirausahaan, VOL.10, NO. 2, September 2008: 124.

${ }^{32}$ Mukni'ah, Jurnal Perilaku ..............hlm. 3.

${ }^{33}$ Matondang,Kepemimpinan Budaya...................hlm. 67.

${ }^{34}$ Atik Novitasari, Agus Wahyudin, Rediana Setiyani, Pengaruh Kepemimpinan Kepala Sekolah, Lingkungan Kerja Pendidikan, dan Pelatihan terhadap Kinerja,(Economic
} 
kepala sekolah berpengaruh signifikan terhadap kinerja guru, serta penelitian yang dilakukan oleh Ester Manik dan Kamel Bustomi, ${ }^{35}$ dengan hasil penelitian bahwa budaya organisasi berpengaruh signifikan terhadap kinerja guru.

\section{Hasil dan Pembahasan}

Pada penelitian ini yang menjadi hipotesis pada metode kuantitatif adalah perilaku kepemimpinan (X1) berpengaruh secara signifikan terhadap kinerja guru pendidikan agama islam.Perilaku kepemimpinan kepala sekolah adalah segala tindakan, reaksi, aktivitas tanggapan dari seorang pemimpin (kepala sekolah) dalam bertindak dan merespon lingkungan sekitarnya dalam rangka menjalankan kepemimpinannya sebagai pimpinan sekolah. Kepemimpinan kepala sekolah dipersepsi oleh guru sebagai perilaku yang berorientasi pada bawahan dalam hubungan pribadi maupun hubungan formal (kedinasan) pada lingkungan sekolah.

Sebagai contoh sekolah sekolah yang ada di Kabupaten Fakfak baik tingkat SDN, SMPN dan SMAN/SMKN saat penelitian saya berlangsung, saya melihat fasilitas yang diberikan para kepala sekolah untuk para guru pendidikan agama islam sudah cukup baik, dengan fasilitas yang sudah di sediakan dari sekolah. Begitu juga para guru dalam berkomunikasi dengan teman sejawatnya, dan berhubungan baik denganatasanya yaitu kepala sekolah. Sebagai salah satu sumber saya ketika meneliti di SD Inpres 2 Fakfak dan SMA Negeri 1 Fakfak, para guru ketika jam istirahat saling mendukung kegiatan belajar mengajar dan saling mengingatkan satu sama lain dalamhal kebaikan.

Berangkat dari indikator-indikator pada variabel yang telah ditetapkan, penelitian kemudian mengkaji literatur-literatur yang dijadikan sebagai sumber/ referensi penelitian dan memiliki korelasi dengan variabel peneltian tersebut untuk mendapatkan item-item penelitian. Untuk subvariabel perilaku kepemimpinan, yang terdiri dari 1) Perilaku yang berorientasi Tugas 2) Perilaku yang berorientasi Hubungan. 3) Perilaku yang berorientasi perubahan.

Sesuai dengan uraian sebelumnya hasil penelitian dengan uji $t$ ditemukan bahwa besaran probabilitas (sig) untuk variabelperilaku kepemimpinanadalah 0,000 dan nilai tersebut lebih kecil dari 0,05 (0,000 $<0,05$ ). Selain itu hasil pengujian juga menunjukkan bahwa nilai koefisien

Education Analysis Journal, Vol. 1 No. 2), 2012.

${ }^{35}$ Ester Manik dan Kamel Bustomi, Jurnal Ekonomi, Bisnis \& Entrepreneurship Vol. 5, No. 2, Oktober 2011, 97-107 ISSN 2443-0633.

$264 \mid$ JURNAL LISAN AL-HAL 
$\mathrm{T}$ (Thitung) yang diperoleh adalah 7,460. Adapun $\mathrm{T}$ Tabel pada df yang sesuai $(\alpha 5 \%, \mathrm{df}=18)$ yaitu 2,018 . Dengan demikian dapat dilihat bahwa besaran probabilitas (sig) $0.000<0,05$ dan thitung $(7,460)>$ ttabel $(42: 0,05)(2,018)$ Dengan demikian pengujian menunjukkan H0 ditolak dan $\mathrm{H} 1$ diterima. Hal ini berartiperilaku kepemimpinan berpengaruh terhadap kinerja guru Pendidikan Agama Islam. Semakin tinggiperilaku kepemimpinan maka akan berpengaruh pada tingginya kinerja guru pendidikan agama islam di Kabupaten Fakfak.

Hasil temuan menunjukkan bahwa perilaku kepemimpinan ternyata memberi pengaruh signifikan tesesuai dengan teori-teori yang terhadap kinerja guru pendidikan agama islam di Kabupaten Fakfak. Hasil temuan penelitian ini sesuai dengan teori-teori yang telah dikemukakan pada bab-bab sebelumnya. Artinya secara teoritis perilaku kepemimpinan mampu meningkatkan kinerja guru pendidikan agama islam. Fakta yang terjadi dilapangan menunjukkan, perilaku yang berorientasi tugas, perilaku yang berorientasi hubungan dan perilaku yang berorientasi perubahanmemberi pengaruh secara positif terhadap kinerja guru pendidikan agama Islam yaitu, menyusun persiapan mengajar, melaksanakan proses belajar mengajar dan menilai proses dan hasil kegiatan mengajar.

Pada penelitian ini yang menjadi hipotesis pada metode kuantitatifadalah Budaya Organisasi (X2) berpengaruh secara signifikan terhadap kinerja guru pendidikan agama islam.Budaya Organisasi adalah suatu bentuk atau cara yang digunakan dalam pemecahan masalah organisasi, baik intern maupun ekstern yang mencakup: filosofi, ideologi, values, asumsi, keyakinan, harapan, sikap, dan norma-norma yang dirajut bersama oleh anggota organisasi dan digunakan dalam pembuatan keputusan dan pemecahan masalah.

Berangkat dari indikator-indikator pada variabel yang telah ditetapkan, penelitian kemudian mengkaji literatur-literatur yang dijadikan sebagai sumber/ referensi penelitian dan memiliki korelasi dengan variabel peneltian tersebut untuk mendapatkan item-item penelitian. Untuk subvariabel budaya organisasi, yang terdiri dari 1) Direction (arah). 2) Integrasi, 3) Dukungan dari manajemen. 4) Kontrol, 5) Identitas, 6) Sistem imbalan, 7) Toleransi terhadap konflik dan kritik secara terbuka. 8) Pola-pola komunikasi.

Sesuai dengan uraian sebelumnya hasil penelitian dengan uji $t$ ditemukan bahwa besaran probabilitas (sig) untuk variabelbudaya organisasi adalah 0,001 dan nilai tersebut lebih kecil dari 0,05 $0,001<$ 0,05). Selain itu hasil pengujian juga menunjukkan bahwa nilai koefisien $\mathrm{T}$

$$
\text { JURNAL LISAN AL-HAL } \mid 265
$$


(Thitung) yang diperoleh adalah 3,451. Adapun T Tabel pada df yang sesuai $(\alpha 5 \%$, df=45)yaitu 2,018. Dengan demikian dapat dilihat bahwa besaran probabilitas (sig) $0.001<0,05$ dan thitung $(3,451)>$ ttabel $(42: 0,05)(2,018)$. Dengan demikian pengujian menunjukkan H0 ditolak dan $\mathrm{H} 1$ diterima. Hal ini berarti budaya organisasi berpengaruh terhadap kinerja guru pendidikan agama islam. Semakin tinggibudaya organisasi maka akan berpengaruh pada tingginya kinerja guru pendidikan agama islam di Kabupaten Fakfak.

Hasil temuan menunjukkan bahwa budaya organisasiternyata memberi pengaruh signifikan sesuai dengan teori-teori terhadap kinerja gurupendidikan agama islamdi Kabupaten Fakfak. Hasil temuan penelitian ini sesuai dengan teori-teori yang telah dikemukakan pada bab-bab sebelumnya. Artinya secara teoritis budaya organisasi mampu meningkatkan kinerja guru pendidikan agama Islam. Fakta yang terjadi dilapangan menunjukkan, direction (arah), integrasi, dukungan dari manajemen, kontrol, identitas, sistem imbalan, toleransi terhadap konflik dan kritik secara terbuka, serta pola-pola komunikasi memberi pengaruh secara positif terhadap kinerja guru pendidikan agama Islam yaitu menyusun persiapan mengajar, melaksanakan proses belajar mengajar dan menilai proses dan hasil kegiatan belajar mengajar.

Pada penelitian ini yang menjadi hipotesis pada metode kuantitatif adalah penggunaan Perilaku Kepemimpinan (X1), dan Budaya Organisasi (X2) berpengaruh secara signifikan terhadap Kinerja GuruPendidikan Agama Islam(Y).Dalam Peraturan Menteri Agama Republik Indonesia nomor 16 tahun 2010 tentang pengelolaan pendidikan agama pada sekolah, Guru Pendidikan Agama harus memiliki 5 Kompetensi, diantaranya adalah: Kompetensi Pedagogik, Kepribadian, Sosial, Profesional dan Kompetensi Kepemimpinan.

Sesuai dengan hasil analisis yang di teliti diperoleh kesimpulan bahwa perilaku kepemimpinan kepala sekolah, budaya organisasi dan kinerja guru pendidikan agama Islam mempunyai hubungan satu sama lain. Masing-masing variabel dependent berpengaruh signifikan terhadap variabel independent. Beberapa penelitian terkait perilaku kepemimpinan kepala sekolah, budaya organisasi dan kinerja yang telah dilakukan oleh beberapa peneliti diantaranya oleh Atik Novitasari, Agus Wahyudi, Rediana setiyani ${ }^{36}$ yang menyimpulkan bahwa perilaku kepemimpinan

\footnotetext{
${ }^{36}$ Atik Novitasari, Agus Wahyudin, Rediana Setiyani, Pengaruh Kepemimpinan Kepala Sekolah, Lingkungan Kerja Pendidikan, dan PelatihanterhadapKinerja,(Economic Education Analysis Journal, Vol. 1 No. 2), 2012.
}

$266 \mid$ JURNAL LISAN AL-HAL 
kepala sekolah berpengaruh signifikan mterhadap kinerja guru, serta penelitian yang dilakukan oleh Ester Manik dan Kamel Bustomi, ${ }^{37}$ dengan hasil penelitian bahwa budaya organisasi berpengaruh signifikan terhadap kinerja guru.

Berdasarkan hasil pengujian menunjukkan bahwa nilai signifikansi uji serempak (uji F) diperoleh nilai 0,000. Dengan demikian nilai signifikansi yang diperoleh lebih kecil dari probabilitas alpha yangditetapkan, yaitu 0,05 (sig. $F<$ probabilitas $\alpha$ ). Selain itu hasil pengujian juga menunjukkan bahwa nilai koefisien $F$ (Fhitung) yang diperoleh adalah 82,142. Adapun FTabel pada df yang sesuai $(\alpha 5 \%$, df1 = 2 dan df2 $=42$ ) yaitu 3,219. Dengan demikian dapat dilihat bahwa besaran probabilitas(Sig) $0.000<0.05$ dan Fhitung $(82,142)>$ Ftabel $(2: 42: 0,05)$ $(3,219)$. Dengan demikian pengujian menunjukkan H0 ditolak dan H1 diterima. Hal ini menunjukkan bahwa ada pengaruh perilaku kepemimpinan kepala sekolah, dan budaya organisasi terhadap kinerja guru pendidikan agama Islam di Kabupaten Fakfak.

Berdasarkan beberapa penelitian terkait diatas, dikemukakan bahwa dari banyaknya faktor yang mempengaruhi kinerja guru pendidikan agama Islam diantaranya adalah factor perilaku kepemimpinan kepala sekolah, dan budaya organisasi. Hasil penelitian ini selaras dengan teori-teori di atas sebagaimana yang telah disebutkan baik secara teoritik maupun empirik yang menunjukkan adanya pengaruh perilaku kepemimpinan kepala sekolah, dan budaya organisasi dengan kinerja guru pendidikan agama islam di kabupaten Fakfak.

Berdasarkan Hasil analisis korelasi yang diperoleh menunjukkan bahwa variabel perilaku kepemimpinan dan budaya organisasi terhadap kinerja guru pendidikan agama islam diperoleh nilai $\mathrm{R}$ sebesar 0,892 yang menunjukkan bahwa korelasi/hubungan antara variabel Perilaku Kepemimpinan (X1), Budaya Organisasi (X2) dengan variabel Kinerja Guru Pendidikan Agama Islam (Y) SD, SMP, SMA dan SMK di kabupaten Fakfak adalah kuat, karena angka ini berada di atas 0,5. Angka Adjusted R square menunjukkan koefisien determinasi. Besar Adjusted $\mathrm{R}$ square adalah 0,787. Hal ini berarti 78,7 \% perubahan variabel Kinerja Guru Pendidikan Agama Islam disebabkan oleh perubahan variable Perilaku Kepemimpinan (X1), dan Budaya Organisasi (X2).

Berdasarkan uraian tersebut maka hipotesis ke tiga yang menyatakan bahwa perilaku kepemimpinan dan budaya organisasi

${ }^{37}$ Ester Manik dan Kamel Bustomi, Jurnal Ekonomi, Bisnis \& Entrepreneurship Vol. 5, No. 2, Oktober 2011, 97-107 ISSN 2443-0633. 
berpengaruh positif dan signifikan terhadap kinerja guru pendidikan agama islam SD, SMP, SMA dan SMK di kabupaten Fakfak. Dengan demikian dapat ditarik kesimpulan bahwa perilaku kepemimpinan dan budaya organisasi secara simultan berpengaruh positif signifikan terhadap kinerja guru pendidikan agama Islam SD, SMP, SMA dan SMK di Kabupaten Fakfak.

Dengan demikian dapat dimengerti bahwa faktor-faktor kinerja gurutersebut akan lebih efektif dan efisien ketika didukung oleh faktor perilaku kepemimpinan yang meliputi: Perilaku yang berorientasi Tugas, Perilaku yang berorientasi hubungan dan Perilaku yang berorientasi perubahan. Dimana seorang guru dapat menjalankan hubugan baik antara sesama guru, kepala sekolah dan kepada staf TU, tidak hanya hubungan sosial yang diterima, namun juga fasilitas yang diberikan kepada guru juga mendukung para guru untuk menjalankan tugasnya sebagai guru. Budaya Organisasi yang diterapkan oleh suatu sekolah menuntut para anggota organisasi untuk menyesuaikan diri terhadap budaya organisasi yang merupakan ciri khas suatu lembaga. Setiap calon anggota yang akan masuk ke dalam organisasi diharuskan menyesuaikan diri dengan budaya yang ada di lembaga.

Faktor lain yang juga menentukan tinggi rendahnya kinerja guru pendidikan agama islam adalah budaya organisasi. Budaya organisasi yang dianut oleh sekolah merupakan sarana untuk meningkatkan kinerja guru pendidikan agama islam dan para pegawai lainnya. Meningkatnya kinerja guru pendidikan agama islam merupaka hasil internalisasi guru terhadap nilai-nilai organisasi sekolah sehingga memunculkan loyalitas serta komitmen yang tinggi kepada sekolah yang pada akhirnya berdampak pada peningkatan kinerja guru pendidikan agama islam di SD, SMP SMA dan SMK yang ada di Kabupaten Fakfak.

\section{E. Simpulan}

Setelah dilakukan analisis hasil penelitian dan pembahasan terhadap hasil dari perilaku kepemimpinan kepala sekolah, budaya organisasi dan kinerja guru pendidikan agama Islam. Maka pada bagian ini akan diuraikan kesimpulan dari pembahasan dan juga saran-saran yang dipandang perlu sebagai masukan bagi pihak-pihak terkait dalam rangka peningkatan kinerja guru pendidikan agama islam. Dari hasil analisis data dan pembahasan hasil penelitian dapat disimpulkan hal-hal sebagai berikut: 1) Pengolahan data secara deskriptif menyatakan bahwa dari 45 responden, lebih dari $80 \%$ menyatakan persetujuanya terhadap pentingnya perilaku kepemimpinan kepala sekolah dan budaya organisasi

$$
268 \mid \text { JURNAL LISAN AL-HAL }
$$


yang baik terhadap peningkatan kinerja guru khususnya guru PAI SD, SMP,SMA/SMK di Kabupaten Fakfak2) Ada pengaruh positif dan signifikan antara perilaku kepemimpinan kepala sekolah dan kinerja guru pendidikan agama islam di Kabupaten Fakfak.Semakin tinggi perilaku kepemipinan kepala sekolah maka akan semakin meningkat pula kinerja guru pendidikan agama islam di Kabupaten Fakfak. 3) Ada pengaruh positif dan signifikan antara budaya organisasi dan kinerja guru pendidikan agama islam di Kabupaten Fakfak. Semakin tinggi budaya organisasi maka akan semakin meningkat pula kinerja guru pendidikan agama islam di Kabupaten Fakfak. 4) Ada pengaruh positif dan signifikan secara simultan perilaku kepemimpinan kepala sekolah dan budaya organisasi terhadap kinerja guru pendidikan agama Islam di Kabupaten Fakfak yaitu sebesar 78,7\% sedangkan sebanyak 21,3 \% dipengaruhi oleh faktor lain.

\section{DAFTAR PUSTAKA}

Bahri, Saiful Optimalisasi Kinerja Kepala Sekolah, Jakarta: Gibon Books, 2010.

Biya, Novi. Pengaruh Kinerja Guru terhadap Hasil Belajar Siswa Mata Pejaran Ekonomi, Jurnal Muhammadiyah Gorontalo, 2012.

Brahmasari, Ida Ayu dan Suprayitno, Agus. Jurnal Manajemen dan Kewirausahaan, VOL.10, NO. 2, September 2008: 124-135.

I Nyoman Rauh, Dantes, Anggan, Kontribusi Gaya Kepemimpinan, Supervisi Akademik Kepala Sekolah, dan Budaya Organisasi terhadap Kinerja Guru SD di Gugus III Kecamatan Sukasada, (e-jurnal Program Pasca Sarjana Universitas pendidikan Ganesha, Vol. 4), 2013.

Manik, Ester dan Bustomi, Kamel. Jurnal Ekonomi, Bisnis\& Entrepreneurship Vol. 5, No. 2, Oktober 2011, 97-107 ISSN 24430633.

Matondang. Kepemimpinan Budaya Organisasi dan Manajemen Strategi. Yogyakarta: GrahaIlmu, 2008.

Mukni'ah, Jurnal Perilaku kepemimpinan kepala sekolah dalam upaya meningkatkan kinerja guru, Vol. 12016.

Noordianti, Yulia. Pengaruh Perilaku Kepemimpinan, Kepala Sekolah, Iklim Kerja dan Motivasi Kerja terhadap Kinerja Guru, (Jurnal Manajemen, Surakarta), 2013.

Novitasari, Atik, Wahyudin, Agus, Rediana Setiyani, Pengaruh Kepemimpinan Kepala Sekolah, Lingkungan Kerja Pendidikan, dan Pelatihan terhadap Kinerja,(Economic Education Analysis Journal,

$$
\text { JURNAL LISAN AL-HAL } \mid 269
$$


Vol. 1 No. 2), 2012.

Peraturan Pemerintah RI No. 66 tahun 2010 tentang Pengelolaan dan Penyelenggaraan Pendidikan, Yogyakarta: Pustaka Yustisia, 2011.

Rekno Wulan, Deriana. Pengaruh Supervisi dan Kepemimpinan Kepala Sekolah terhadap Motivasi untuk Peningkatan Kinerja Guru, 2015.

Rikha Handayani, Yusrawati, Pengaruh Profesionalisme, Komitmen Organisasi dan Budaya Kerja terhadap Kinerja Internal, (Jurnal Manajemen Ekonomi, Vol. 21 No. 2), 2013.

Rinwati, Anita, Pengaruh Kinerja Guru terhadap Motivasi Belajar Siswa, Jurnal Universitas Muhammadiyah Purworejo (Vol. 2 Juni 2012).

Roslen Septiana, Ngadiman, Elvia Ivada, Pengaruh Kepemimpinan Kepala Sekolah dan Motivasi Kerja terhadap Kinerja Guru PAI Wonosari, (Jurnal Pendidikan Ekonomi, Vol 2 No. 1), 2013.

Rozaki, Firmanika. Pengaruh Motivasi dan Budaya Organisasi terhadap Kinerja Guru SMK YPT 2 Purbalingga, (jurnal e Abstract Excellent Vol. 2 No. 2), 2016.

Samsul Bahri, Pengaruh Motivasi, Tindakan supervisi dan Budaya Organisasi terhadap Kinerja Auditor Junior), (Jurnal Fakultas Ekonomi dan Bisnis UIN Syarif Hidayatullah), 2012.

Sugiono. Metode Penelitian Kuantitatif, Kualitatif, R\&D. Bandung: Alfabeta Cetakan ke 22, 2015.

Sulistiani, Pengaruh Kepemimpinan Kepala Sekolah, Iklim Kerja, Kompetensi Profesional Guru terhadap Kinerja Guru di MTs Kepanjen, (Jurnal Riset Pendidikan Ekonomi, Vol. 1 No. 1), 2016.

Susanto, Ahmad. Manajemen Peningkatan Kinerja Guru. Jakarta: Prenada media Group, 2016.

Sutisna, Oteng. Administrasi Pendidikan Dasar Teoritis untuk Praktik Profesional, Bandung: Angkasa, 1993.

Sutrisno, Edy. Budaya Organisasi, (Jakarta: Prenamedia Group, 2015).

Tiogas, Donald M.F. Pengaruh Kepemimpinan Kepala Sekolah, Supervisi dan kepuasan Kerja Guru terhadap Kinerja Guru MIPA di Yayasan Pendidikan Advent Timika, (Jurnal lmu Pendidikan Indonesia, Vol. 2 No. 3), 2014.

Undang-Undang RI Nomor 20 Tahun 2003 tentang Sistem pendidikan Nasional, Yogyakarta: Pustaka Yustisia, 2011.

Wahjosumidjo, Kepemimpinan Kepala Sekolah, Tinjauan Teoritik dan Permasalahannya Kepala Sekolah. Jakarta: PT. Raja Grafindo Persada, 1999.

Wahyuningsih, Sri Rahayu. Tesis Pengaruh Kepemimpinan Kepala Sekolah Terhadap Kinerja Guru Sd Negeri Di Lingkungan Unit Pelaksana

$270 \mid$ JURNAL LISAN AL-HAL 
Teknis Pendidikan Kecamatan Sukagumiwang Kabupaten Indramayu, 2011 Jakarta

Wijoyoko, Eko Putro. Analisi Pengaruh Kinerja Guru terhadap Motivasi Belajar Siswa, Jurnal Pendidikan 2015.

Yonatan, Pengaruh Budaya dan Komitmen Organisasional terhadap Kinerja Karyawan, (Jurnal Agora, Vol. 2 No. 1), 2014. 
"Perilaku Kepemimpinan Kepala Sekolah"

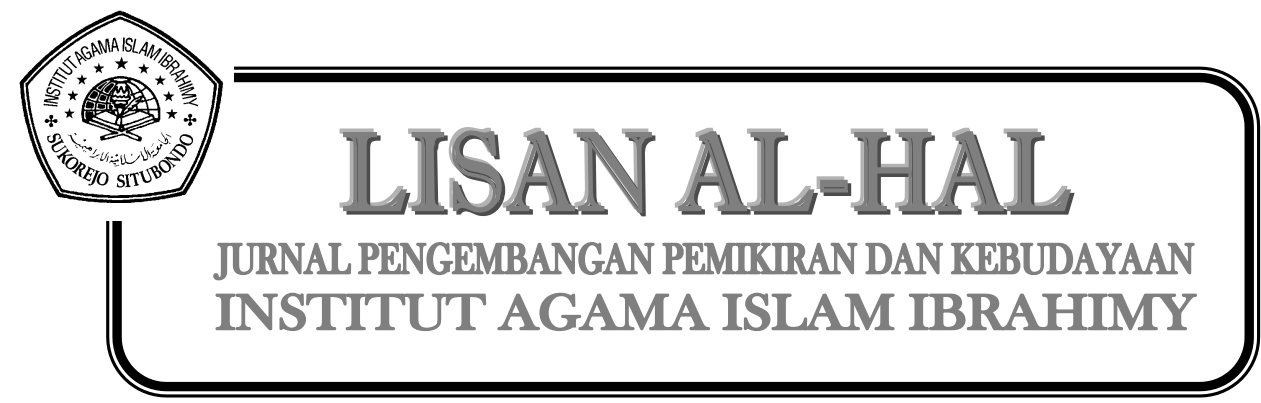

272 JURNAL LISAN AL-HAL 